\title{
Impact of the addition of different plant residues on nitrogen mineralization-immobilization turnover and carbon content of a soil incubated under laboratory conditions
}

\author{
M. Kaleeem Abbasi, M. Mahmood Tahir, N. Sabir, and M. Khurshid \\ Department of Soil and Environmental Sciences, University of Poonch, Rawalakot Azad Jammu and Kashmir, Pakistan \\ Correspondence to: M. Kaleem Abbasi (mkaleemabbasi@gmail.com)
}

Received: 15 September 2014 - Published in Solid Earth Discuss.: 23 October 2014

Revised: 9 January 2015 - Accepted: 21 January 2015 - Published: 13 February 2015

\begin{abstract}
Application of plant residues as soil amendment may represent a valuable recycling strategy that affects carbon $(\mathrm{C})$ and nitrogen $(\mathrm{N})$ cycling in soil-plant systems. The amount and rate of nutrient release from plant residues depend on their quality characteristics and biochemical composition. A laboratory incubation experiment was conducted for 120 days under controlled conditions $\left(25^{\circ} \mathrm{C}\right.$ and $58 \%$ waterfilled pore space) to quantify initial biochemical composition and $\mathrm{N}$ mineralization of leguminous and non-leguminous plant residues, i.e., the roots, shoots and leaves of Glycine max, Trifolium repens, Zea mays, Populus euramericana, Robinia pseudoacacia and Elaeagnus umbellata, incorporated into the soil at the rate of $200 \mathrm{mg}$ residue $\mathrm{N} \mathrm{kg}^{-1}$ soil. The diverse plant residues showed a wide variation in total $\mathrm{N}, \mathrm{C}$, lignin, polyphenols and $\mathrm{C} / \mathrm{N}$ ratio with higher polyphenol content in the leaves and higher lignin content in the roots. The shoot of Glycine max and the shoot and root of Trifolium repens displayed continuous mineralization by releasing a maximum of $109.8,74.8$ and $72.5 \mathrm{mg} \mathrm{N} \mathrm{kg}^{-1}$ and representing a 55, 37 and $36 \%$ recovery of $\mathrm{N}$ that had been released from these added resources. The roots of Glycine max and Zea mays and the shoot of Zea mays showed continuous negative values throughout the incubation. After an initial immobilization, leaves of Populus euramericana, Robinia pseudoacacia and Elaeagnus umbellata exhibited net mineralization by releasing a maximum of $31.8,63.1$ and $65.1 \mathrm{mg} \mathrm{N} \mathrm{kg}^{-1}$, respectively, and representing a 16, 32 and $33 \% \mathrm{~N}$ recovery, respectively. Nitrogen mineralization from all the treatments was positively correlated with the initial residue $\mathrm{N}$ contents $(r=0.89 ; p \leq 0.01)$ and negatively correlated with lignin content $(r=-0.84$; $p \leq 0.01), \mathrm{C} / \mathrm{N}$ ratio $(r=-0.69 ; p \leq 0.05)$, lignin $/ \mathrm{N}$ ra-
\end{abstract}

tio $(r=-0.68 ; p \leq 0.05)$, polyphenol $/ \mathrm{N}$ ratio $(r=-0.73$; $p \leq 0.05)$ and (lignin + polyphenol $): \mathrm{N}$ ratio $(r=-0.70$; $p \leq 0.05)$ indicating a significant role of residue chemical composition and quality in regulating $\mathrm{N}$ transformations and cycling in soil. The present study indicates that incorporation of plant residues strongly modifies the mineralizationimmobilization turnover (MIT) of soil that can be taken into account to develop synchronization between net $\mathrm{N}$ mineralization and crop demand in order to maximize $\mathrm{N}$ delivery and minimize $\mathrm{N}$ losses.

\section{Introduction}

Application of organic materials as soil amendments is an important management strategy that can improve and uplift soil-quality characteristics and alter the nutrient cycling through mineralization or immobilization turnover of added materials (Khalil et al., 2005; Campos et al., 2013; Baldi and Toselli, 2014; Novara et al., 2013; Hueso-González et al., 2014; Oliveira et al., 2014). Use of local organic materials derived either from livestock or plants have been attaining worldwide support for improving the fertility and productivity potential of degraded and nutrient-poor soils (Huang et al., 2004; Tejada and Benítez, 2014). Indeed, plant residues and animal manures are potentially important sources of nutrients for crop production in smallholder agriculture. However, the Hindu Kush Himalayan regions, including the state of Azad Jammu and Kashmir, have a wide diversity of leguminous species and non-leguminous plants compared to the livestock production. Hence, use of plant residues as organic nutrient source is relatively simple for the farmers 
compared to the application of manure. Incorporating plant residues into agricultural soils can sustain organic carbon content, improve soil physical properties, enhance biological activities and increase nutrient availability (Hadas et al., 2004; Cayuela et al., 2009). In the short-term, incorporation of plant residues provides the energy and nutrients for microbial growth and activity, acts as a driving force for the mineralization-immobilization processes in the soil and is a source of nitrogen $(\mathrm{N})$ for plants (Jansson and Persson, 1982). In the long-term, incorporation of crop residues is important for the maintenance of organic carbon (C) and $\mathrm{N}$ stocks in the nutrient pool of arable soils (Rasmussen and Parton, 1994).

Incorporation of crop residues provides readily available $\mathrm{C}$ and $\mathrm{N}$ to soils depending upon the decomposition rates and synchrony of nutrient mineralization (Murungu et al., 2011). The $\mathrm{N}$ availability from these residues depends on the amount of $\mathrm{N}$ mineralized or immobilized during decomposition. However, previous studies demonstrated that the decomposition and nutrient release rates of residues are often regulated by environmental factors, such as temperature and soil moisture, and biochemical composition of plant materials and their interaction (Abiven et al., 2005; Khalil et al., 2005). The biochemical composition or quality parameters such as total $\mathrm{N}$ concentration, lignin (LG), polyphenols (PP), carbon : nitrogen $(\mathrm{C} / \mathrm{N})$ ratio, $\mathrm{LG} / \mathrm{N}, \mathrm{PP} / \mathrm{N}$ and $(\mathrm{LG}+\mathrm{PP}) / \mathrm{N}$ ratios are considered useful indicators that control decomposition and $\mathrm{N}$ release of added residues (Nakhone and Tabatabai, 2008; Vahdat et al., 2011; Abera et al., 2012). However, it has not been clearly established which of these variables correlate best with $\mathrm{N}$ mineralization of plant residues (Nakhone and Tabatabai, 2008), as contrasting results have been reported in the literature (Nourbakhsh and Dick, 2005). On the one hand, it has been reported that $\mathrm{N}$ released from leguminous tree leaves indicated that the (lignin + polyphenol) : $\mathrm{N}$ ratio was the most important factor in predicting $\mathrm{N}$ mineralization (Mafongoya et al., 1998). On the other hand, Frankenberger and Abdelmagid (1985) suggested that lignin content of the legumes is not a good predictor of the $\mathrm{N}$ mineralization. Handayanto et al. (1994) suggested that the $\mathrm{N}$ concentration or lignin: $\mathrm{N}$ ratio of the leaves were not good indicators of $\mathrm{N}$ release for agroforestry materials. Palm and Sanchez (1991) attributed the differences in $\mathrm{N}$ mineralization rates of various tropical legumes to polyphenols. Handayanto et al. (1994) found, however, that the total $\mathrm{N}$ content of plant residues was not correlated with rates of $\mathrm{N}$ released under non-limiting $\mathrm{N}$ conditions.

Earlier studies clearly demonstrated the beneficial effects of plant residues on soil-plant systems (Huang et al., 2004; Cayuela et al., 2009; Khalil et al., 2005; Baldi and Toselli, 2014). However, there is still a scope to explore the possibilities for achieving maximum benefits in term of rate, time and amount of $\mathrm{N}$ released. For example, the synchronization of net $\mathrm{N}$ mineralization with plant/crop growth is desirable to maximize $\mathrm{N}$ delivery for the crop and minimize $\mathrm{N}$ losses.
Abiven et al. (2005) reported that one of the tools to achieve synchronization is the use of plant residues with different natures and qualities. Application of residues with a high $\mathrm{C} / \mathrm{N}$ ratio results in immediate net $\mathrm{N}$ immobilization while residues with a low $\mathrm{C} / \mathrm{N}$ ratio result in net $\mathrm{N}$ mineralization, showing that mineralization-immobilization turnover (MIT) can be influenced differently by chemical components of added plant materials. To achieve this target, the combination of legumes and non-legumes plant materials or different plant components of the same plant species, i.e., root, shoot and leaves, can be tested.

Keeping in mind the beneficial effects of plant residues on soil-plant systems, especially in the mountainous upland soils vulnerable to soil (water) erosion, the present work aims to (i) examine the initial biochemical composition and quality characteristics of on-farm available plant residues and to (ii) quantify the $\mathrm{N}$-release potential (mineralization) of these residues added to a soil incubated under controlled laboratory conditions $\left(25^{\circ} \mathrm{C}\right)$ in Rawalakot, Azad Jammu and Kashmir, Pakistan.

\section{Materials and methods}

\subsection{Soil sampling}

The soil used in this study was collected from an arable field located at the research farm of the Faculty of Agriculture of the University of Poonch, Rawalakot, Azad Jammu and Kashmir, Pakistan. The study site is located at latitude $33^{\circ} 51^{\prime} 32.18^{\prime \prime} \mathrm{N}$, longitude $73^{\circ} 45^{\prime} 34.93^{\prime \prime} \mathrm{E}$ and an elevation of $1638 \mathrm{~m}$ above sea level. The climate of the region is subtemperate. Mean daily maximum and minimum air temperatures ranged from 27 to $29^{\circ} \mathrm{C}$ (June-July) and 1.0 to $-3.5^{\circ} \mathrm{C}$ (January-February). The mean annual rainfall ranged between 1100 and $1500 \mathrm{~mm}$ with more than $50 \%$ of the total precipitation during monsoon each year. The soil in the study site was clay loam in texture, classified as Humic Lithic Eutrudepts (Inceptisols; Ali et al., 2006). The field was bare at the time of sampling but previously maize (Zea mays L.) and wheat (Triticum aestivum L.) were cultivated. The selected field was divided into 10 subplots to ensure proper and representative soil sampling. Soil samples were collected from a depth of $0-15 \mathrm{~cm}$ at random from three points in each plot using a soil auger of $5 \mathrm{~cm}$ in diameter. The soil samples from all the selected plots were thoroughly mixed to get a composite sample. The field-fresh soil was passed through a $4 \mathrm{~mm}$ sieve to eliminate coarse rock and plant material, thoroughly mixed to ensure uniformity and stored at $4{ }^{\circ} \mathrm{C}$ before use (not more than 2 weeks). A subsample of about $0.5 \mathrm{~kg}$ was taken, air dried, passed through a $2 \mathrm{~mm}$ sieve and used for the determination of physical and chemical characteristics. The original soil analysis is presented in Table 1. 
Table 1. Selected physicochemical properties of the soil used in the study.

\begin{tabular}{ll}
\hline Soil properties & Values \\
\hline Bulk density $\left(\mathrm{Mg} \mathrm{m}^{-3}\right)$ & 1.20 \\
Particle density $\left(\mathrm{Mg} \mathrm{m}^{-3}\right)$ & 2.48 \\
Porosity $(\%)$ & 48.3 \\
Sand $\left(\mathrm{g} \mathrm{kg}^{-1}\right)$ & 241 \\
Silt $\left(\mathrm{g} \mathrm{kg}^{-1}\right)$ & 394 \\
Clay $\left(\mathrm{g} \mathrm{kg}^{-1}\right)$ & 365 \\
Texture class & clay loam \\
pH & 7.2 \\
$\mathrm{CEC}\left(\mathrm{cmol} \mathrm{kg}^{-1}\right)$ & 7.3 \\
Organic matter $\left(\mathrm{g} \mathrm{kg}^{-1}\right)$ & 10.4 \\
Organic C $\left(\mathrm{g} \mathrm{kg}^{-1}\right)$ & 6.03 \\
Total N $\left(\mathrm{g} \mathrm{kg}^{-1}\right)$ & 0.58 \\
$\mathrm{C}: \mathrm{N} \mathrm{ratio}$ & $10: 1$ \\
Total mineral N $\left(\mathrm{mg} \mathrm{kg}^{-1}\right)$ & 8.7 \\
Total organic N $\left(\mathrm{mg} \mathrm{kg}^{-1}\right)$ & 591.0 \\
$\mathrm{P}\left(\mathrm{mg} \mathrm{kg}^{-1}\right)$ & 3.4 \\
$\mathrm{~K}\left(\mathrm{mg} \mathrm{kg}^{-1}\right)$ & 88.0 \\
Fe $\left(\mathrm{mg} \mathrm{kg}^{-1}\right)$ & 15.7 \\
$\mathrm{Mn}\left(\mathrm{mg} \mathrm{kg}^{-1}\right)$ & 17.0 \\
$\mathrm{Cu}\left(\mathrm{mg} \mathrm{kg}^{-1}\right)$ & 1.02 \\
$\mathrm{Zn}\left(\mathrm{mg} \mathrm{kg}^{-1}\right)$ & 1.16 \\
\hline
\end{tabular}

\subsection{Collection of plant residues}

Six predominant on-farm available plant species were selected. These included Glycine max shoot, Glycine max root, Trifolium repens shoot, Trifolium repens root, Zea mays shoot, Zea mays root, and leaves of Populus euramericana, Robinia pseudoacacia and Elaeagnus umbellata. Plant samples/residues were collected at different times during the year 2012. Glycine max and Trifolium repens samples were collected from the field before flowering (summer) while Zea mays samples were taken 1 week before crop harvest. The tree leaves were sampled in late fall. Plant residues were washed with running tap water, rinsed three times with distilled water, dried at $65^{\circ} \mathrm{C}$ for $48 \mathrm{~h}$, milled and passed through a $1 \mathrm{~mm}$ sieve. Triplicate samples of plant residue were taken and analyzed for their $\mathrm{C}, \mathrm{N}$, lignin and polyphenol concentrations. Total $\mathrm{N}$ contents of the residues were determined by Kjeldhal digestion, distillation and the titration method (Bremner and Mulvaney, 1982). Wet digestion method was used for organic C analysis (Nelson and Sommers, 1982). The lignin content was determined using Van Soest methods (Van Soest et al., 1991). Soluble polyphenols were extracted in hot water $\left(100^{\circ} \mathrm{C}, 1 \mathrm{~h}\right)$ and determined by colorimetry using a Folin-Denis reagent (Folin and Denis, 1915).

\subsection{Laboratory incubation}

The incubation methods used in this study were followed by the methods used in our previous studies (Abbasi et al., 2011; Abbasi and Khizar, 2012). Briefly stated, about $100 \mathrm{~g}$ of soil already stored in the refrigerator at $4{ }^{\circ} \mathrm{C}$ was weighed and transferred into $200 \mathrm{~mL}$ glass jars. The initial moisture content of the soil was $28 \%(w / w)$, which was increased by adding distilled water to achieve a final water-filled pore space of $58 \%$. The treatments were comprised of a control (no N) and nine plant residues sources, i.e., Glycine max shoot, Glycine max root, Trifolium repens shoot, Trifolium repens root, Zea mays shoot, Zea mays root, and leaves of Populus euramericana, Robinia pseudoacacia and Elaeagnus umbellata; 10 incubation timings, i.e., 0, 7, 14, 21, 28, 42, 60, 80, 100 and 120 days; and three replications. Altogether, a total of 300 jars (10 treatments $\times 10$ incubation timings $\times 3$ replications) were arranged in a completely randomized design. Plant residues were weighed and added into the jars at a rate equivalent to $200 \mathrm{mg} \mathrm{N} \mathrm{kg}^{-1}$. After adding residues, all the jars were weighed and their weights were recorded. The soil was then incubated under controlled conditions at $25^{\circ} \mathrm{C}$. Soil moisture was checked/adjusted after every 2 days by weighing the glass jars and adding the required amount of distilled water when the loss was greater than $0.05 \mathrm{~g}$.

\subsection{Soil extraction and analysis}

Samples of all 10 treatments were analyzed for total mineral nitrogen (TMN) as described previously (Abbasi and Khizar, 2012). Initial concentration of $\mathrm{TMN}\left(\mathrm{NH}_{4}^{+}-\mathrm{N}+\mathrm{NO}_{3}^{-}-\mathrm{N}\right)$ on day 0 was determined by extracting soil samples with $200 \mathrm{~mL}$ of $1 \mathrm{M} \mathrm{KCl}$ added directly to the flask immediately after incorporation of each $\mathrm{N}$ source. Thereafter, triplicate samples from each treatment were removed randomly from the incubator at different incubation timings and extracted by shaking for $1 \mathrm{~h}$ with $200 \mathrm{~mL}$ of $1 \mathrm{M} \mathrm{KCl}$ followed by filtration. The total mineral $\mathrm{N}$ of the extract was determined by using the steam distillation and titration method (Keeney and Nelson, 1982). Net cumulative $\mathrm{N}$ mineralized (NCNM) from different plant-residue treatments was calculated following the method described previously (Sistani et al., 2008).

\subsection{Statistical analysis}

All data were statistically analyzed by multifactorial analysis of variance using the software package MSTATC Version 3.1 (1990). Least-significant differences (LSD) were used as a post hoc test to indicate significant variations within the values of either treatments or time intervals. Correlation $(r)$ between initial quality characteristics of the plant residues (total nitrogen, LG, PP and their ratios) and net $\mathrm{N}$ mineralization and the correlation among quality traits were also conducted using SPSS Statistics version 20.0 for Mac (IBM 
Table 2. Mean biochemical composition of the plant residues used in the experiment $(n=3)$.

\begin{tabular}{|c|c|c|c|c|c|c|c|c|c|}
\hline $\begin{array}{l}\text { Plant residues } \\
\text { (treatments) }\end{array}$ & Plant organs & Total N & $\begin{array}{r}\text { Total C } \\
\text { (LG) }\end{array}$ & $\begin{array}{r}\text { Lignin } \\
(\mathrm{PP})\end{array}$ & Polyphenols & $\mathrm{C} / \mathrm{N}$ & LG / N & $\mathrm{PP} / \mathrm{N}$ & $\mathrm{LG}+\mathrm{PP} / \mathrm{N}$ \\
\hline \multicolumn{10}{|c|}{$\mathrm{g} \mathrm{kg}^{-1}$} \\
\hline Glycine $\max$ & shoot & $35.2 \mathrm{a}$ & $447 \mathrm{c}$ & $11 \mathrm{f}$ & $13.1 \mathrm{f}$ & 12.7 & 0.3 & 0.4 & 0.7 \\
\hline Glycine $\max$ & root & $12.8 \mathrm{e}$ & $466 b$ & $29 \mathrm{~d}$ & $26.9 \mathrm{~d}$ & 36.4 & 2.3 & 2.1 & 4.4 \\
\hline Zea mays & shoot & $9.6 \mathrm{f}$ & $472 \mathrm{ab}$ & $41 b$ & $29.5 \mathrm{~cd}$ & 49.2 & 4.3 & 3.1 & 7.3 \\
\hline Zea mays & root & $4.0 \mathrm{~g}$ & $486 a$ & $48 \mathrm{a}$ & $31.4 \mathrm{c}$ & 121.5 & 12.0 & 7.9 & 19.9 \\
\hline Trifolium repens & shoot & $27.4 \mathrm{~b}$ & $397 \mathrm{~g}$ & $13 f$ & $18.0 \mathrm{e}$ & 14.4 & 0.4 & 0.6 & 1.1 \\
\hline Trifolium repens & root & $16.0 \mathrm{~d}$ & $423 \mathrm{de}$ & $21 \mathrm{e}$ & $20.2 \mathrm{e}$ & 26.4 & 1.3 & 1.2 & 2.5 \\
\hline Populus euramericana & leaves & $20.8 \mathrm{c}$ & $435 \mathrm{~cd}$ & $34 c$ & $53.8 \mathrm{a}$ & 20.9 & 1.6 & 2.6 & 4.2 \\
\hline Robinia pseudoacacia & leaves & $33.3 \mathrm{a}$ & $404 f g$ & $28 \mathrm{~d}$ & $32.3 \mathrm{c}$ & 12.1 & 0.8 & 1.0 & 1.8 \\
\hline Elaeagnus umbellata & leaves & $34.7 \mathrm{a}$ & $418 \mathrm{ef}$ & $32 \mathrm{~cd}$ & $38.7 b$ & 12.1 & 0.9 & 1.1 & 2.0 \\
\hline $\operatorname{LSD}(p \leq 0.05)$ & - & 3.14 & 14.16 & 4.53 & 3.77 & - & - & - & - \\
\hline
\end{tabular}

Note: different letters in each column show significant differences among treatments with $p \leq 0.05$

Corp., 2011). A probability level of $p \leq 0.05$ was considered significant (Steel and Torrie, 1980).

\section{Results and discussion}

\subsection{Chemical composition of the residues - residue quality}

A significant difference $(p \leq 0.05)$ among different residue treatments was observed for different components of the plant residues presented in Table 2 . The total $\mathrm{N}$ ranged from a minimum of 4.0 to a maximum of $35.2 \mathrm{~g} \mathrm{~kg}^{-1}$. Shoots of Glycine max and leaves of Robinia pseudoacacia and Elaeagnus umbellata displayed the highest $\mathrm{N}$ compared to the remaining treatments (Table 2). The total $\mathrm{C}$ contents varied between $397 \mathrm{~g} \mathrm{~kg}^{-1}$ in the Trifolium repens shoot and a maximum of $486 \mathrm{~g} \mathrm{~kg}^{-1}$ in the Zea mays root. Zea mays (both shoot and root) displayed the highest $\mathrm{C}$ contents compared to the remaining plant-residue treatments. The $\mathrm{C}: \mathrm{N}$ showed a similar trend recorded for residue $\mathrm{C}$ content. The LG content varied between a minimum of $11 \mathrm{~g} \mathrm{~kg}^{-1}$ in the Glycine max shoot and a maximum of $48 \mathrm{~g} \mathrm{~kg}^{-1}$ in the Zea mays roots. Similarly, a minimum PP content $\left(13.1 \mathrm{~g} \mathrm{~kg}^{-1}\right)$ was recorded in the Glycine max shoot while a maximum PP $\left(52.8 \mathrm{~g} \mathrm{~kg}^{-1}\right)$ was found in the Populus euramericana leaves. The LG / N, PP / N and LG+PP / N ratios were highest in the Zea mays root while the lowest values were recorded in the Glycine max shoot. Generally, total N contents of the legume residues were higher compared to the non-legumes. Similarities could be observed between the same organs of the different species, i.e., all the roots were characterized by high C, LG and PP contents and lower N concentration. Leaves were particularly rich in PP and total N. The differences in the concentration of quality characteristics of residues according to plant components, i.e., shoot, root and leaves, have been reported previously (Abiven et al., 2005;
Nourbakhsh and Dick, 2005). It has been reported that high lignin content in root was due to the presence of suberin in the roots and its ability to form complex barriers when associated with lignin (Abiven et al., 2005). Plant residues used in this study provided a wide range of contrasted chemical composition and significant variation in quality characteristics because of the difference in (i) type of species, i.e., leguminous and non-leguminous, trees and crops, and (ii) plant components/organs, i.e., shoot, root and leaves.

\subsection{Nitrogen mineralization}

Analysis of variance showed that $\mathrm{N}$ mineralization was significantly $(p \leq 0.05)$ affected by the treatments and the incubation timings, while the interaction between the treatments and the timings was also significant. Results indicated that the control soil without any amendment released a maximum of $77.7 \mathrm{mg} \mathrm{N} \mathrm{kg}^{-1}$ on day 100 compared to $13.7 \mathrm{mg} \mathrm{kg}^{-1}$ at the start, showing a substantial release of $\mathrm{N}$ into mineral $\mathrm{N}$ pool (Table 3). Expressed as the total $\mathrm{N}$ initially present, the net $\mathrm{N}$ mineralized during the incubation was $14 \%$. The mineralization of native soil $\mathrm{N}$ observed here was in accordance with our previous study where a maximum of $90 \mathrm{mg} \mathrm{kg}^{-1}$ mineral $\mathrm{N}$ was released from the control soil, representing $16 \%$ of the initial $\mathrm{N}$ of the soil (Abbasi and Khizar, 2012). Among different plant materials added, the legumes, i.e., the shoot of Glycine max and shoot and root of Trifolium repens, exhibited significantly higher TMN compared to the nonlegumes. The maximum TMN released from these amendments varied between 150 and $189 \mathrm{mg} \mathrm{kg}^{-1}$. The mean values indicated that these legumes were collectively able to release $85 \mathrm{mg} \mathrm{N} \mathrm{kg}^{-1}$ compared to $20 \mathrm{mg} \mathrm{kg}^{-1}$ by maize and $58 \mathrm{mg} \mathrm{N} \mathrm{kg}^{-1}$ by leaves of the non-legumes trees. As expected, the plant organs also affected $\mathrm{N}$ mineralization and, in general, roots displayed significantly lower TMN compared to the shoot and leaves. Incorporation of Glycine max 
Table 3. Mean changes in the concentration of total mineral $\mathrm{N}$ of a soil amended with different plant residues and incubated at $25^{\circ} \mathrm{C}$ under controlled laboratory conditions during a 120-day period $(n=3)$.

\begin{tabular}{|c|c|c|c|c|c|c|c|c|c|c|c|}
\hline \multirow[b]{2}{*}{ Treatments } & \multicolumn{10}{|c|}{ Days after plant-residue addition } & \multirow[b]{2}{*}{$\operatorname{LSD}(p \leq 0.05)$} \\
\hline & 0 & 7 & 14 & 21 & 28 & 42 & 60 & 80 & 100 & 120 & \\
\hline \multicolumn{12}{|c|}{$\mathrm{mg} \mathrm{N} \mathrm{kg}^{-1}$ soil } \\
\hline Control & 13.7 & 13.9 & 12.9 & 17.1 & 30.9 & 65.9 & 63.1 & 75.6 & 77.7 & 51.7 & 2.88 \\
\hline$T_{1}$ & 14.8 & 39.2 & 49.2 & 76.8 & 96.7 & 158.1 & 165.2 & 174.1 & 188.7 & 160.9 & 7.90 \\
\hline$T_{2}$ & 13.7 & 8.1 & 5.2 & 8.3 & 11.8 & 13.8 & 28.4 & 50.4 & 49.4 & 27.7 & 8.15 \\
\hline$T_{3}$ & 13.7 & 7.4 & 6.2 & 6.9 & 10.5 & 23.1 & 21.2 & 36.1 & 46.7 & 21.0 & 5.34 \\
\hline$T_{4}$ & 14.3 & 7.4 & 9.4 & 7.7 & 8.8 & 15.3 & 22.2 & 21.4 & 32.4 & 26.4 & 4.30 \\
\hline$T_{5}$ & 14.1 & 19.0 & 21.6 & 55.5 & 62.5 & 86.8 & 127.6 & 150.8 & 145.8 & 93.3 & 7.31 \\
\hline$T_{6}$ & 15.5 & 8.2 & 5.2 & 23.9 & 34.0 & 85.3 & 98.0 & 149.9 & 130.2 & 85.8 & 9.46 \\
\hline$T_{7}$ & 13.0 & 5.7 & 4.1 & 8.6 & 22.6 & 55.5 & 73.1 & 106.8 & 87.3 & 66.9 & 8.39 \\
\hline$T_{8}$ & 13.9 & 7.4 & 9.2 & 23.6 & 46.6 & 91.3 & 111.0 & 138.9 & 127.8 & 93.7 & 7.83 \\
\hline$T_{9}$ & 12.9 & 9.4 & 14.5 & 25.3 & 51.1 & 80.1 & 92.7 & 140.0 & 116.4 & 93.5 & 6.88 \\
\hline $\operatorname{LSD}(p \leq 0.05)$ & 2.43 & 4.77 & 3.12 & 5.11 & 7.63 & 8.23 & 6.87 & 9.23 & 8.27 & 7.34 & \\
\hline
\end{tabular}

$T_{0}$ is the control; $T_{1}$ is Glycine max shoot, $T_{2}$ is Glycine max root; $T_{3}$ is Zea mays shoot, $T_{4}$ is $Z$. mays root; $T_{5}$ is Trifolium repens shoot; $T_{6}$ is Trifolium repens root; $T_{7}$ are Populus euramericana leaves; $T_{8}$ are Robinia pseudoacacia leaves; $T_{9}$ are Elaeagnus umbellata leaves. LSD represents the least significant difference $(p \leq 0.05)$ among incubation periods (within rows) and among the treatments (within column).

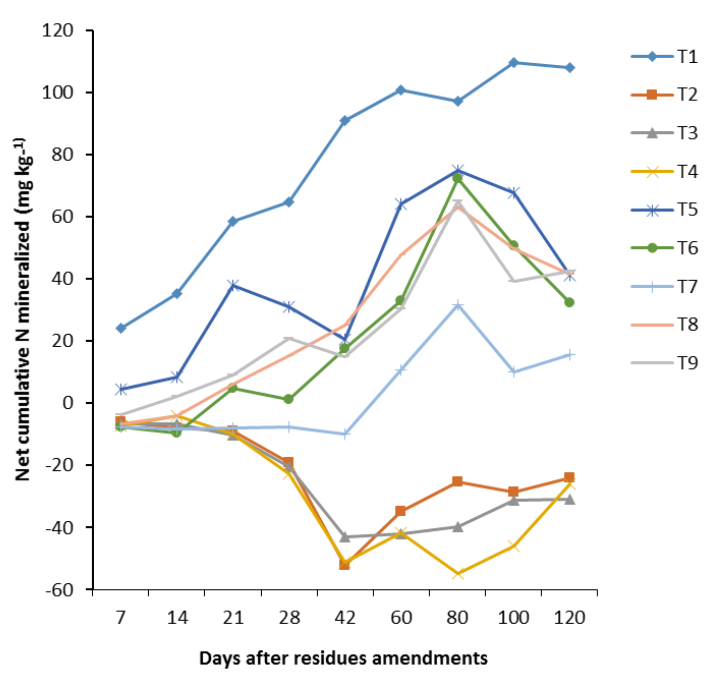

Figure 1. Net cumulative $\mathrm{N}$ mineralized from the added plant residues at different incubation periods. Legend: $T_{1}$ is Glycine max shoot, $T_{2}$ is Glycine max root; $T_{3}$ is Zea mays shoot, $T_{4}$ is Zea mays root; $T_{5}$ is Trifolium repens shoot; $T_{6}$ is Trifolium repens root; $T_{7}$ are Populus euramericana leaves; $T_{8}$ are Robinia pseudoacacia leaves; $T_{9}$ are Elaeagnus umbellata leaves.

root and Zea mays shoot and root resulted in a constant decrease in TMN, and the maximum values ranged between 32 and $49 \mathrm{mg} \mathrm{kg}^{-1}$ compared to $78 \mathrm{mg} \mathrm{kg}^{-1}$ in the control treatment. However, after initial negative values until day 14 and 21, leaves of Populus euramericana, Robinia pseudoacacia and Elaeagnus umbellata continuously increased TMN until reaching between 107 and $140 \mathrm{mg} \mathrm{kg}^{-1}$ (highest values).

\subsection{Net cumulative $\mathbf{N}$ mineralization}

Nitrogen mineralization of added plant residues was determined on the basis of net cumulative $\mathrm{N}$ mineralized. The $\mathrm{N}$ mineralization from Glycine max and Trifolium repens shoot showed positive values throughout the incubation, ranging from 24 to $110 \mathrm{mg} \mathrm{kg}^{-1}$ for Glycine max and 5 to $75 \mathrm{mg} \mathrm{kg}^{-1}$ for Trifolium repens (Fig. 1). Considering the NCNM at the end day 120 , the net $\mathrm{N}$ mineralized as percentage of total $\mathrm{N}$ applied from Glycine max and Trifolium repens shoot was 54 and $21 \%$, respectively. The percent of $\mathrm{N}$ mineralized from Glycine max shoot had been reported previously and ranged from 39 to $43 \%$ of applied $\mathrm{N}$ residues (Nakhone and Tabatabai, 2008). However, the NCNM from Glycine max roots, Zea mays shoot and Zea mays roots exhibited negative values throughout the incubation, indicating net immobilization. Among the three residues, Zea mays roots displayed higher negative values leading to higher immobilization. Roots of Glycine max and leaves of Populus euramericana, Robinia pseudoacacia and Elaeagnus umbellata showed four phases of mineralization-immobilization turnover: initial negative values from days 7 to 21 , slow mineralization from days 21 to 60, a rapid mineralization between days 60 and 80 and a decline in net between days 100 and 120. The net $\mathrm{N}$ mineralized as percentage of total $\mathrm{N}$ applied from roots of Glycine max and leaves of Populus euramericana, Robinia pseudoacacia and Elaeagnus umbellata was 16, 8, 21 and $21 \%$, respectively. Net nitrogen mineralization ( $\%$ of added $\mathrm{N}$ ) from different organic materials during 110 days of incubation was in the range of $-35 \%$ in Triticum aestivum (wheat) residues to $81 \%$ in Trifolium repens (white clover) residues (Kumar and Goh, 2003). Similarly, a 44, 38 and $35 \%$ of $\mathrm{N}$ added had been released from 


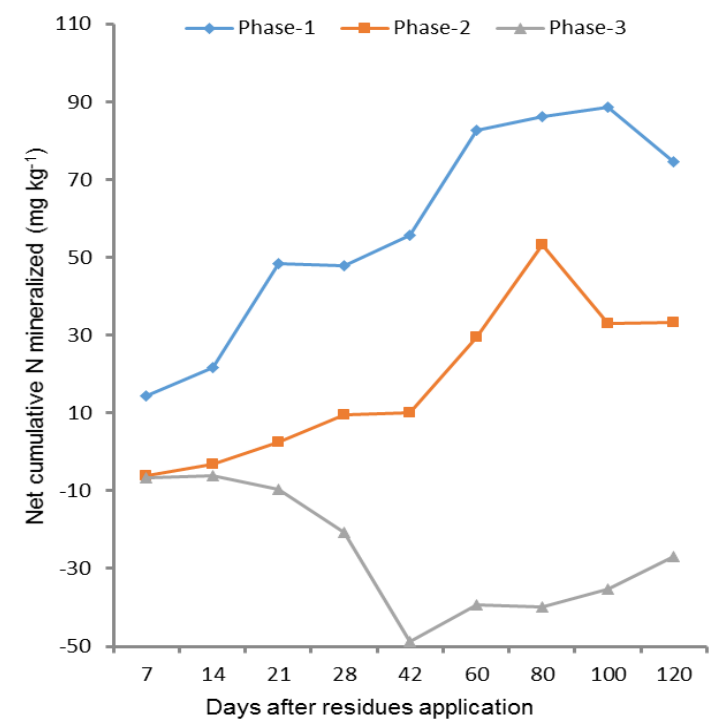

Figure 2. The mineralization-immobilization turnover of added plant residues representing three phases during 120 days incubation.

the leaves of peanut, pigeon pea and hairy indigo, respectively (Thippayarugs et al., 2008).

All legumes (except Glycine max root) exhibited the highest NCNM (average $30 \%$ of added plant $\mathrm{N}$ residues) compared to non-legumes (17\%). Similarly, the cereal crop Zea mays shoot and root exhibited net immobilization compared to net mineralization observed in the legumes and tree leaves. The plant components also showed variation in NCNM. For example, shoots of Glycine max and Trifolium repens mineralized an average of $74 \mathrm{mg} \mathrm{N} \mathrm{kg}^{-1}$ compared to $4 \mathrm{mg} \mathrm{N} \mathrm{kg}^{-1}$ from the roots. Likewise, leaves of forest trees showed higher NCNM compared to the roots of legumes and non-legumes crop.

The shoots of Glycine max and Trifolium repens exhibited the highest NCNM without any negative value during incubation because of high $\mathrm{N}$ concentration and a low $\mathrm{C} / \mathrm{N}$ ratio. However, it is interesting to note that the total $\mathrm{N}$ concentration of the leaves of Robinia pseudoacacia and Elaeagnus umbellata was higher and $\mathrm{C} / \mathrm{N}$ ratio was lower compared to the Trifolium repens shoot, but the net mineralization (averaged) of Trifolium repens shoot was higher (47 and $58 \%$ ) compared to the leaves of Robinia pseudoacacia and Elaeagnus umbellata, respectively. The low mineralization in leaves in spite of high $\mathrm{N}$ content and low $\mathrm{C} / \mathrm{N}$ ratio was attributed to higher concentration of LG, PP, LG / N, PP / N and $\mathrm{LG}+\mathrm{PP} / \mathrm{N}$. These results demonstrated the effect of other factors in addition to total $\mathrm{N}$ and $\mathrm{C} / \mathrm{N}$ ratio on plantresidue decomposition and $\mathrm{N}$ mineralization kinetics. As indicated in a previous study (Trinsoutrot et al., 2000), the net accumulation (whether positive or negative) of mineral $\mathrm{N}$ in soil during decomposition of organic residues is directly related to the residue $\mathrm{N}$ content. However, our results clearly
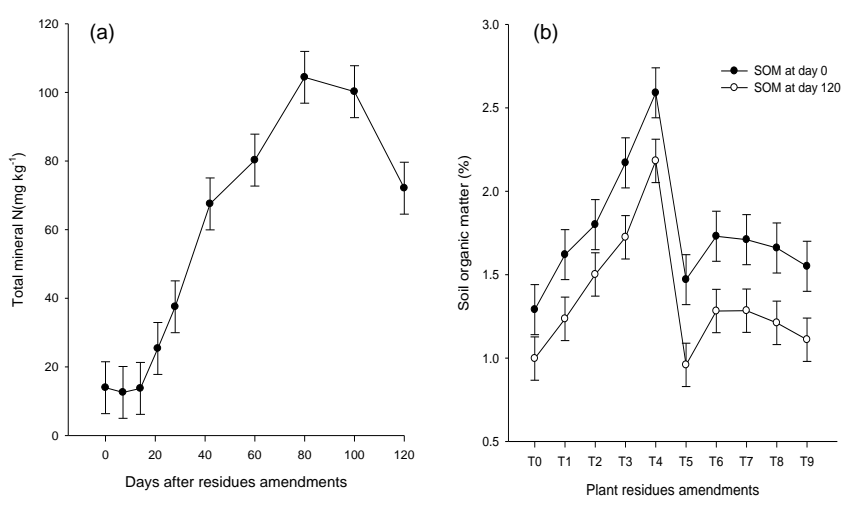

Figure 3. Mineralization trend of added plant residues across timings (a) and soil organic matter (SOM) turnover of different plant residues recorded at the start of the experiment on day 0 and at the end of incubation on day 120 (b). The hanging bar on each major line represents the LSD $(p \leq 0.05)$ between incubation periods and between each treatment.

indicated that $\mathrm{N}$ was not the only factor affecting the mineralization of added residues; some additional quality characteristics also influenced MIT of plant residues. Likewise, the total $\mathrm{N}$ content and $\mathrm{C} / \mathrm{N}$ ratio of the leaves of Robinia pseudoacacia and Elaeagnus umbellata were on par with Glycine max shoot but the net mineralization of Glycine max shoot was 3-fold higher. It had been reported that organic materials with similar $\mathrm{C}$ / $\mathrm{N}$ ratios may mineralize different amounts of $\mathrm{N}$ because of differences in composition that are not reflected by the $\mathrm{C} / \mathrm{N}$ ratio (e.g., different lignin contents) (Mohanty et al., 2011).

Similarly, roots of Glycine max and Zea mays showed net immobilization while roots of Trifolium repens displayed fast decomposition and net $\mathrm{N}$-release pattern. This discrepancy in root MIT was mainly due to high $\mathrm{N}$ concentration, low C / N ratio and low LG and PP contents of the roots of Trifolium repens. The $\mathrm{N}$ turnover shown by Trifolium repens roots confirmed the strong below-ground $\mathrm{N}$ dynamics and residual effect of Trifolium repens when grown in the soil.

Among the leaves of different trees tested, leaves of Robinia pseudoacacia and Elaeagnus umbellata released a substantial amount of $\mathrm{N}$ into the mineral $\mathrm{N}$ pool. Leaf residues have been described as high-quality litter materials in terms of high $\mathrm{N}$ and low lignin contents (Thippayarugs et al., 2008) and have been found to decompose easily and release mineral N substantially (Mtambanengwe and Kirchmann, 1995) as observed in our study. However, Populus euramericana leaves exhibited higher net immobilization (for a longer period) and lower net mineralization. The variation was again due to disparity in the biochemical composition. The low $\mathrm{N}$ content, high $\mathrm{C} / \mathrm{N}$ ratio and high PP content may have been largely responsible for the slow decomposition and low net mineralization of Populus euramericana leaves. These results inferred that the same plant components may not necessarily show similar decomposition and 
Table 4. Pearson linear correlation coefficients between initial quality characteristics of the plant residues and net $\mathrm{N}$ mineralization and correlation within plant-quality characteristics.

\begin{tabular}{lrrrrrrr}
\hline & $N_{\min }$ & TN & LG & PP & C:N & LG:N & PP :N \\
\hline TN & $0.89^{* *}$ & & & & & & \\
LG & $-0.84^{* *}$ & $-0.66^{*}$ & & & & & \\
PP & $-0.42 \mathrm{~ns}$ & $-0.10 \mathrm{~ns}$ & $0.62^{*}$ & & & & \\
C $: \mathrm{N}$ & $-0.69^{*}$ & $-0.80^{* *}$ & $0.73^{*}$ & $0.07 \mathrm{~ns}$ & & & \\
LG $: \mathrm{N}$ & $-0.68^{*}$ & $-0.76^{* *}$ & $0.77^{* *}$ & $0.14 \mathrm{~ns}$ & $0.99^{* *}$ & & \\
PP $\mathrm{N}$ & $-0.73^{*}$ & $-0.77^{* *}$ & $0.82^{* *}$ & $0.29 \mathrm{~ns}$ & $0.99^{* *}$ & $0.98^{* *}$ & \\
LG + PP $: \mathrm{N}$ & $-0.70^{*}$ & $-0.76^{* *}$ & $0.79^{* *}$ & $0.19 \mathrm{~ns}$ & $0.99^{* *}$ & $1.00^{* *}$ & $0.99^{* *}$ \\
\hline
\end{tabular}

** and * represent significant levels at $p \leq 0.01$ and $p \leq 0.05$, respectively; the correlation significance and non-significance level was calculated at $p \leq 0.05$. The abbreviations represent $\mathrm{N}$ mineralization $\left(N_{\min },\right)$, total nitrogen (TN), lignin (LG) and polyphenols (PP).

mineralization turnover because of the variation in biochemical composition.

In general, the added plant residues increased organic matter stock in soil and thereby increased $\mathrm{N}$ mineralization and $\mathrm{N}$ transformation processes in soil. Plant or crop residues, when added or incorporated into the soil, increase the organic matter (avoid the climate change), reduce the soil and water losses and increase the biological activity in the soils. Such changes bring a substantial improvement in the physical, chemical and microbial properties of soil and eventually in the soil quality (Giménez Morera et al., 2010; Jiménez et al., 2013; Zhao et al., 2013; Singh et al., 2014; Prats et al., 2014)

\subsection{Pattern and trend of $\mathrm{N}$ mineralization}

The patterns of $\mathrm{N}$ mineralization varied among plant residues and plant components. After incorporation into soil and during incubation, the added residues exhibited three main patterns of cumulative net mineralization (Fig. 2): (i) a pattern of the continuous and rapid release of net $\mathrm{N}$ throughout the incubation without showing any negative value indicating net mineralization, shown by the Glycine max shoot and Trifolium repens shoot; (ii) a pattern shown by the Trifolium repens roots and Populus euramericana, Robinia pseudoacacia and Elaeagnus umbellata leaves indicated initial negative values of net cumulative immobilization for variable periods followed by slow and then a rapid release of $\mathrm{N}$, indicating immobilization-mineralization turnover; (iii) a pattern of continuous negative values throughout the incubation, indicating net $\mathrm{N}$ immobilization as seen in the case of the Glycine max root and the Zea mays shoot and root. The MIT and Nrelease patterns by plant residues observed here were in accordance with those reported previously in both leguminous and non-leguminous plant residues (Kumar and Goh, 2003).

The $\mathrm{N}$ mineralization trend over time showed wide variation (Fig. 3a). These results highlighted the time taken for releasing $\mathrm{N}$ into the mineral $\mathrm{N}$ pool by the added plant residues. Results showed an initial lag phase where most of the applied residues endured immobilization with little mineralization; only the Glycine max and Trifolium repens shoots showed mineralization during 0 to 21 days of incubation. The rapid mineralization phase occurred from day 28 to day 80 . Thereafter a declining phase of mineralization started toward the later part of the incubation from day 100 to day 120 .

\subsection{Changes in soil organic matter}

In order to examine the changes in soil organic matter (SOM) in response to added plant residues, a comparison between the SOM at the start of day 0 and the end of incubation on day 120 has been shown (Fig. 3b). Soil organic matter contents of all the treatments recorded on day 120 were lower than those recorded on day 0 . The unaccounted SOM ranged between 32 and $67 \%$ compared to that recorded on day 0 . The decreasing trend of SOM was substantially higher for the treatments showing mineralization (54-67\%) compared to those showing immobilization (32$38 \%$ ). By the end of day 120, the loss of SOM was in the following order: Trifolium repens shoot $>$ Elaeagnus umbellata leave $>$ Trifolium repens $\operatorname{root}=$ Robinia pseudoacacia leaves $>$ Populus euramericana $>$ Glycine $\max$ shoot $>\mathrm{Zea}$ mays shoot $>$ Zea mays root = Glycine max root. The SOM turnover observed here coincided with net mineralization. In the initial lag phase when mineralization was either very low or displayed negative values, on average only $8 \%$ of the initial SOM had been utilized (7-21 days). The SOM utilization during days $28-80$ when mineralization was rapid was $31 \%$ of the initial amount, while $43 \%$ of initial SOM was utilized in the later part of incubation (between days 100 and 120) when mineralization start showing a declining trend.

\subsection{Relationship between cumulative $\mathbf{N}$ mineralization and residue-quality characteristics}

Results of the study showed highly significant positive correlation between $\mathrm{N}$ mineralization and plant-residue $\mathrm{N}$ concentrations $(r=0.89 ; p \leq 0.01)$ (Table 4$)$. In contrast, a negative significant correlations existed between net cumulative $\mathrm{N}$ mineralized and LG $(r=-0.84 ; p \leq 0.01)$, NCNM and 
$\mathrm{C} / \mathrm{N}$ ratio $(r=-0.69 ; p \leq 0.05), \mathrm{NCNM}$ and $\mathrm{LG} / \mathrm{N}$ ratio $(r=-0.68 ; p \leq 0.05), \mathrm{NCNM}$ and $\mathrm{PP} / \mathrm{N}$ ratio $(r=-0.73$; $p \leq 0.05)$ and $\mathrm{NCNM}$ and $\mathrm{LG}+\mathrm{PP} / \mathrm{N}$ ratio $(r=-0.70$; $p \leq 0.05$ ). The correlation between $\mathrm{N}$ mineralization and $\mathrm{PP}$ was nonsignificant with $p \leq 0.05$. The significant positive correlation between net rates of $\mathrm{N}$ mineralization and residue $\mathrm{N}$ concentration observed is consistent with other studies (Nourbakhsh and Dick, 2005; Vahdat et al., 2011). It has been reported that $\mathrm{N}$ availability may control the decomposition of plant residues, particularly those with low $\mathrm{N}$ content such as cereals, when the $\mathrm{N}$ requirements of the soil decomposers are not met by the residue or soil $\mathrm{N}$ contents (Vahdat et al., 2011). A negative correlation was also observed between net $\mathrm{N}$ mineralization and $\mathrm{C} / \mathrm{N}$ ratio of the plant materials. Previously, total $\mathrm{N}$ contents and $\mathrm{C} / \mathrm{N}$ ratio were considered adequate for predicting the net $\mathrm{N}$ mineralization of crop residue. However, the latest studies, including the present work, highlight the role of other quality characteristics, including LG and PP, that affect net mineralization of plant residues. The closer relationship between net mineralization and residue lignin contents $(r=-0.84 ; p \leq 0.01)$ than that of the $\mathrm{C} / \mathrm{N}$ ratio $(r=-0.69 ; p \leq 0.05)$ recorded in this study was in accordance with previous findings (Vahdat et al., 2011). The highly significant positive correlation between net $\mathrm{N}$ mineralization and the residue $\mathrm{N}$ content $(r=0.89 ; p \leq 0.01)$ confirms the previous results (Nourbakhsh and Dick, 2005; Vahdat et al., 2011), indicating that residue $\mathrm{N}$ concentration can be considered a better tool to predict mineralization of added organic residues compared to the $\mathrm{C} / \mathrm{N}$ ratio.

\section{Conclusions}

The experiment showed that soil amended with plant residues displayed wide variation of $\mathrm{N}$ mineralization depending on the plant species and plant components/organs. The decomposition and N-release potential of added materials were largely related to their biochemical composition. In addition to residue $\mathrm{N}$ concentration and $\mathrm{C} / \mathrm{N}$ ratio, $\mathrm{LG}$ contents of plant residues also appeared to be an important factor in predicting the net $\mathrm{N}$ mineralization of plant residues. Shoots of Glycine max and Trifolium repens and leaves of Robinia pseudoacacia and Elaeagnus umbellata exhibited a substantial mineralization potential, demonstrating that legumes and trees of these two plant species can produce high-quality residues and thus have the potential to promote $\mathrm{N}$ cycling in agroecosystems. This study suggested that plant residues showing rapid mineralization can be used for early $\mathrm{N}$ demands of a crop, while residues with high $\mathrm{C}: \mathrm{N}$ and LG contents immobilize $\mathrm{N}$ and thus can help to counter the $\mathrm{N}$ loss generally observed due to rapid ammonificationnitrification turnover. Use of such plant materials in our cropping systems, especially in the regions subjected to land degradation, may be a useful management strategy to restore these soils for agriculture production.
Acknowledgements. The authors express their appreciation to Nuclear Institute for Food and Agriculture, Peshawar, Pakistan for providing lab facilities to analyze biochemical characteristics of the plant materials used in the study.

Edited by: P. Pereira

\section{References}

Abbasi, M. K. and Khizar, A.: Microbial biomass carbon and nitrogen transformations in a loam soil amended with organicinorganic $\mathrm{N}$ sources and their effect on growth and $\mathrm{N}$-uptake in maize, Ecol. Eng., 39, 23-132, 2012.

Abbasi, M. K., Hina, M., and Tahir, M. M.: Effect of Azadirachta indica (neem), sodium thiosulphate and calcium chloride on changes in nitrogen transformations and inhibition of nitrification in soil incubated under laboratory conditions, Chemospher, 82, 1629-1635, 2011.

Abera, G., Wolde-meskel, E., and Bakken, L. R.: Carbon and nitrogen mineralization dynamics in different soils of the tropics amended with legume residues and contrasting soil moisture contents. Biol. Fertil. Soils, 48, 51-66, 2012.

Abiven, S., Recous, S., Reyes, V., and Oliver, R.: Mineralisation of $\mathrm{C}$ and $\mathrm{N}$ from root, stem and leaf residues in soil and role of their biochemical quality, Biol. Fertil. Soils, 42, 119-128, 2005.

Ali, B., Mohmand, H., and Muhammad, F.: Integrated land resource survey and evaluation of Azad Jammu \& Kashmir area 2004, Soil Survey of Pakistan, Government of Pakistan, Ministry of Food, Agriculture \& Livestock, 156-157, 2006.

Baldi, E. and Toselli, M.: Mineralization dynamics of different commercial organic fertilizers from agro-industry organic waste recycling: an incubation experiment, Plant Soil Environ., 60, 93-99, 2014.

Bremner, J. M. and Mulvaney, C.S.: Nitrogen-total, in: Methods of Soil Analysis Part 2 Chemical and Microbiological Properties, edited by: Page, A. L., Miller, R. H., and Keeney, D. R., SSSA Madison, WI, 595-624, 1982.

Campos, A. C., Etchevers, J. B., Oleschko, K. L., and Hidalgo, C. M.: Soil microbial biomass and nitrogen mineralization rates along an altitudinal gradient on the cofre de perote volcano (Mexico): the importance of landscape position and land use, Land Degrad. Dev., 25, 581-593, doi:10.1002/ldr.2185, 2013.

Cayuela, M. L., Sinicco, T., and Mondini, V.: Mineralization dynamics and biochemical properties during initial decomposition of plant and animal residues in soil, Appl. Soil Ecol., 48, 118$127,2009$.

Folin, O. and Denis, W.: A colorimetric estimation of phenol and phenol and derivatives in urine, J. Biol. Chem., 22, 305-308, 1915.

Frankenberger Jr., W. T., and Abdelmagid, H. M.: Kinetic parameters of nitrogen mineralization rates of leguminous crops incorporated into soil, Plant Soil, 87, 257-271, 1985.

Giménez Morera, A., Ruiz Sinoga, J. D., and Cerdà, A: The impact of cotton geotextiles on soil and water losses in Mediterranean rainfed agricultural land, Land Degrad. Dev., 210-217, doi:10.1002/ldr.971, 2010.

Hadas, A., Kautsky, L., Goek, M., and Kara, E. E.: Rates of decomposition of plant residues and available nitrogen in soil, related to 
residue composition through simulation of carbon and nitrogen turnover, Soil Biol. Biochem., 36, 255-266, 2004.

Handayanto, E., Cadish, G., and Giller, K. E.: Nitrogen release from prunings of hedgerow trees in relation to the quality of the pruning and incubation method, Plant Soil, 160, 237-248, 1994.

Huang, Y., Zou, J., Zheng, X., Wang, Y., and Xu, X.: Nitrous oxide emissions as influenced by amendment of plant residues with different C : N ratios, Soil Biol. Biochem., 36, 973-981, 2004.

Hueso-González, P., Martínez-Murillo, J. F., and Ruiz-Sinoga, J. D.: The impact of organic amendments on forest soil properties under Mediterranean climatic conditions, Land Degrad. Dev., 25, 604-612, doi:10.1002/ldr.2296, 2014.

Jansson, S. L. and Persson, J.: Mineralization and immobilization of soil nitrogen, in: Nitrogen in Agricultural Soils, edited by: Stevenson, F. J., ASA, SSSA Special Publication No. 22, Madison WI, 229-252, 1982.

Jiménez, M. N., Fernández-Ondoño, E., Ripoll, M. Á., CastroRodríguez, J., Huntsinger, L., and Navarro, F. B.: Stones and organic mulches improve the Quercus ilex L, afforestation success under Mediterranean climatic conditions, Land Degrad. Dev., online first, doi:10.1002/ldr.2250, 2013.

Keeny, D. R. and Nelson, D. W.: Nitrogen - inorganic forms, in: Methods of Soil Analysis Part 2 Chemical and Microbiological Properties, eddied by: Page, A. L., Miller, R. H., and Keeney D. R., SSSA Madison WI, 643-693, 1982.

Khalil, M. I., Hossain, M. B., and Schmidhalte, U.: Carbon and nitrogen mineralization in different upland soils of the subtropics treated with organic materials, Soil Biol. Biochem. ,37, 15071518, 2005.

Kumar, K. and Goh, K. M.: Nitrogen release from crop residues and organic amendments as affected by biochemical composition, Commun. Soil Sci. Plant Anal., 34, 2441-2460, 2003.

Mafongoya, P. L., Nair, P. K. R., and Dzowela, B. H.: Mineralization of nitrogen from decomposing leaves of multipurpose trees as affected by their chemical composition, Biol. Fertil. Soils, 27, 143-148, 1998.

Mohanty, M., Reddy, K. S., Probert, M. E., Dalal, R. C., Subba Rao, A., and Menzie, N. W.: Modeling $\mathrm{N}$ mineralization from green manure and farmyard manure from a laboratory incubation study, Ecol. Model., 222, 719-726, 2011.

MSTATC: A microcomputer program for the design, management, and analysis of agronomic research experiments, Michigan State University, Michigan, USA, 1990.

Mtambanengwe, F. and Kirchmann, H.,: Litter from a tropical savanna woodland (miombo): chemical composition and $\mathrm{C}$ and $\mathrm{N}$ mineralization, Soil Biol. Biochem., 27, 1639-1651, 1995.

Murungu, F. S., Chiduza, C., Muchaonyerwa, P., and Mnkeni, P. N. S.: Decomposition, nitrogen, and phosphorus mineralization from residues of summer-grown cover crops and suitability for a smallholder farming system in South Africa, Commun. Soil Sci. Plant Anal., 42, 2461-2472, 2011.

Nakhone, L. N. and Tabatabai, M. A.: Nitrogen mineralization of leguminous crops in soils, J. Plant Nutr. Soil Sci., 171, 231-241, 2008.
Nelson, D. N. and Sommer, L. E.: Total carbon, organic carbon and organic matter, in: Methods of Soil Analysis Part 2 Chemical and Microbiological Properties, edited by: Page, A. L., Miller, R. H., and Keeney, D. R., SSSA Madison, WI, 539-589, 1982.

Nourbakhsh, F., and Dick, R. P.: Net nitrogen mineralization or immobilization potential in a residue-amended calcareous soil, Arid. Land. Res. Manage., 19, 299-306, 2005.

Novara, A., Gristina, L., Rühl, J., Pasta, S., D’Angelo, G., La Mantia, T., and Pereira, P.: Grassland fire effect on soil organic carbon reservoirs in a semiarid environment, Solid Earth, 4, 381-385, doi:10.5194/se-4-381-2013, 2013.

Oliveira, S. P., Lacerda, N. B., Blum, S. C., Escobar, M. E. O., and Oliveira, T. S.: Organic carbon and nitrogen stocks in soils of northeastern brazil converted to irrigated agriculture, Land Degrad. Dev., 26, 9-21, doi:10.1002/ldr.2264, 2014.

Palm, C. A. and Sanchez, P. A.: Nitrogen release from the leaves of some tropical legumes as affected by their lignin and polyphenolic contents, Soil Biol. Biochem., 23, 83-88, 1991.

Prats, S. A., Malvar, M.C., Simões-Vieira, D. C., MacDonald, L., and Keizer, J. J.: Effectiveness of hydro- mulching to reduce runoff and erosion in a recently burnt pine plantation in central Portugal, Land Degrad. Dev., online first, doi:10.1002/ldr.2236, 2014.

Rasmussen, P. E. and Parton, W. J.: Long term effects of residue management in wheat-fallow: I. Inputs, yield, and soil organic matter, Soil Sci. Soc. Am. J., 58, 523-530, 1994.

Singh, K., Trivedi, P., Singh, G., Singh, B., and Patra, D. D.: Effect of different leaf litters on carbon, nitrogen and microbial activities of sodic soils, Land Degrad. Dev., online first, doi:10.1002/ldr.2313, 2014.

Sistani, K. R., Adeli, A., McGowen, S. L., Tewolde, H., and Brink, G. E.: Laboratory and field evaluation of broiler litter nitrogen mineralization, Bioresour. Technol., 99, 2603-2611, 2008.

Steel, R. G. D. and Torrie, J. H.: Principles and Procedure of Statistics, McGrraw Hill Book Co Inc, New York, 1980.

Tejada, M. and Benítez, C.: Effects of crushed maize straw residues on soil biological properties and soil restoration, Land Degrad. Dev., 25, 501-509, doi:10.1002/ldr.2316, 2014.

Thippayarugs, S., Toomsan, B., Vityakon, P., Limpinuntana, V., Patanothai, A., and Cadisch, G. G.: Interactions in decomposition and $\mathrm{N}$ mineralization between tropical legume residue components, Agr. Forest. Syst., 72, 137-148, 2008.

Trinsoutrot, I., Recous, S., Mary, B., and Nicolardot, B.: C and $\mathrm{N}$ flux of decomposing ${ }^{13} \mathrm{C}$ and ${ }^{15} \mathrm{~N}$ Brassica napus $\mathrm{L}$.: effect of residue composition and $\mathrm{N}$ content, Soil Biol. Biochem., 32, 1717-1730, 2000.

Vahdat, E., Nourbakhsh, F., and Basiri, M.: Lignin content of range plant residues controls N mineralization in soil, Eur. J. Soil Biol., 47, 243-246, 2011.

Van Soest, P. J., Robertson, J. B., and Lewis, B.,A.: Methods for dietary fiber, neutral detergent fiber and non-starch polysaccharides in relation to animal nutrition, J. Dairy Sci., 74, 3584-3597, 1991.

Zhao, G., Mu, X., Wen, Z., Wang, F., and Gao, P.: Soil erosion, conservation, and eco-environment changes in the loess plateau of China, Land Degrad. Dev., 24, 499-510, doi:10.1002/ldr.2246, 2013. 